
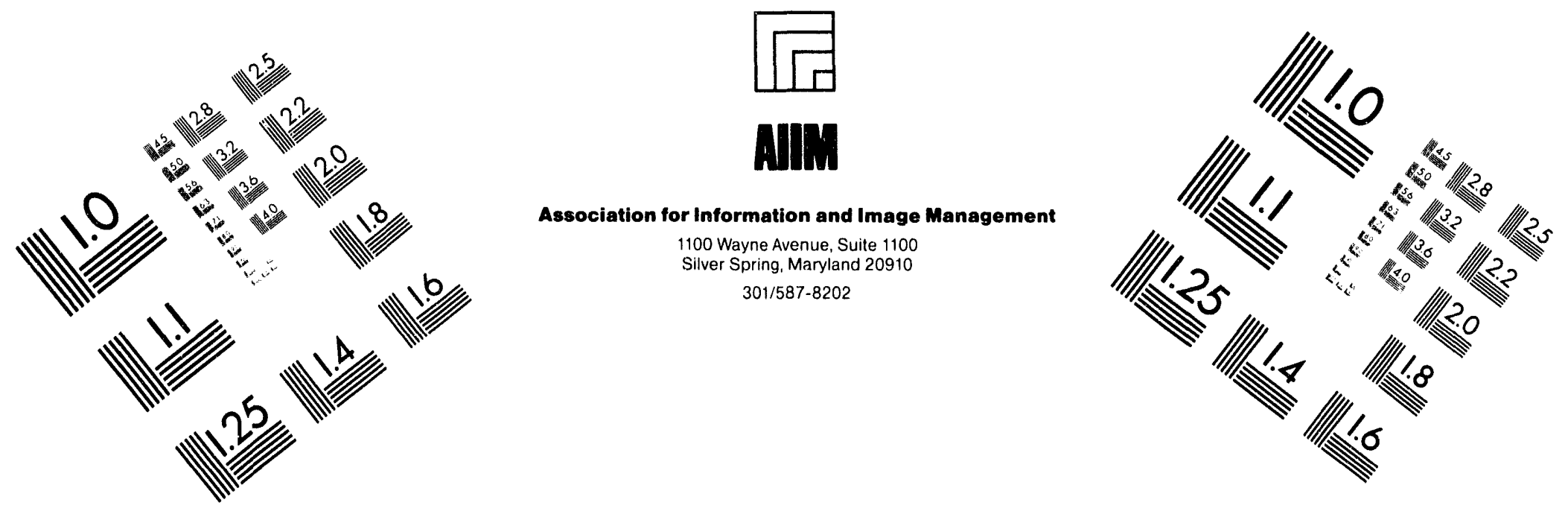

\title{
Centimeter
}

|

Inchies
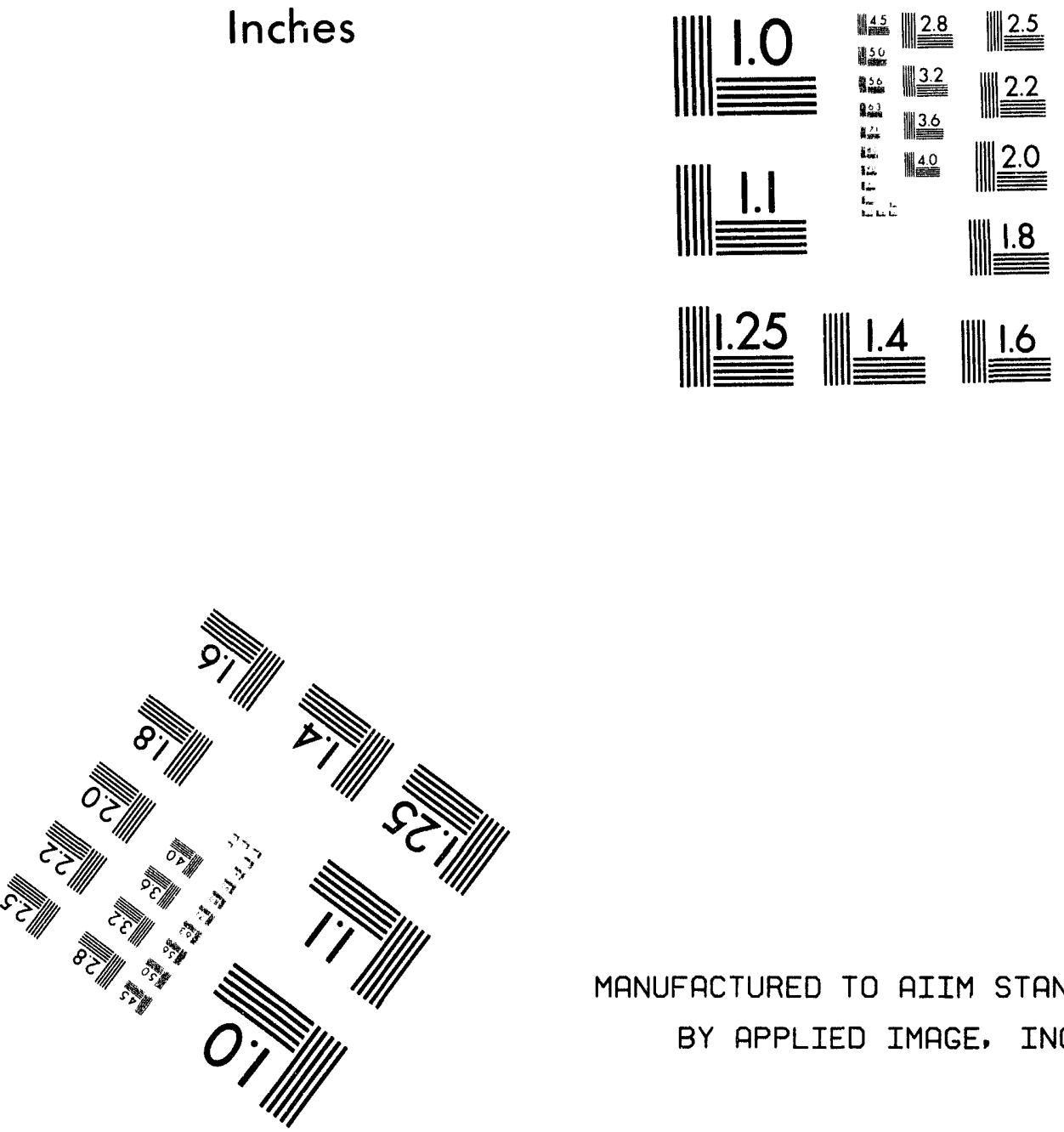

MANUFACTURED TO AIIM STANDARDS

BY APPLIED IMAGE, INC.

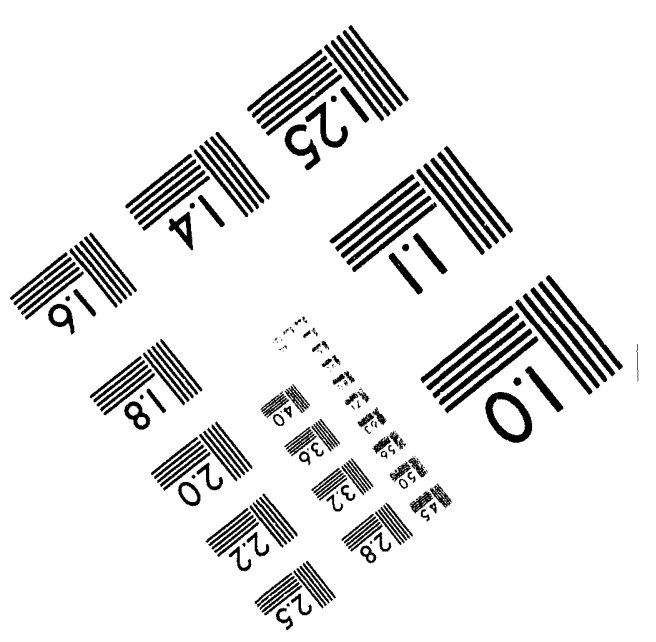



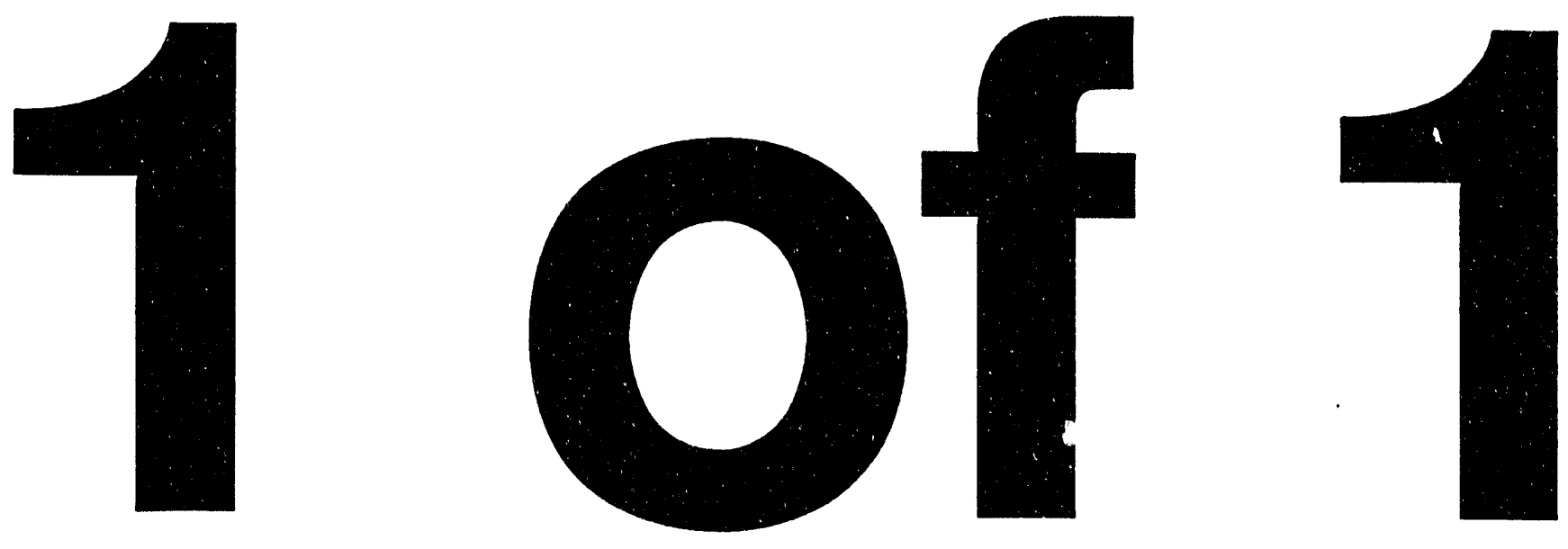


\section{GENERAL ELECTRIC}

HANFOND ATOMIC PRODUCTB OPERATION - RICHLAND, WAEHINGTON

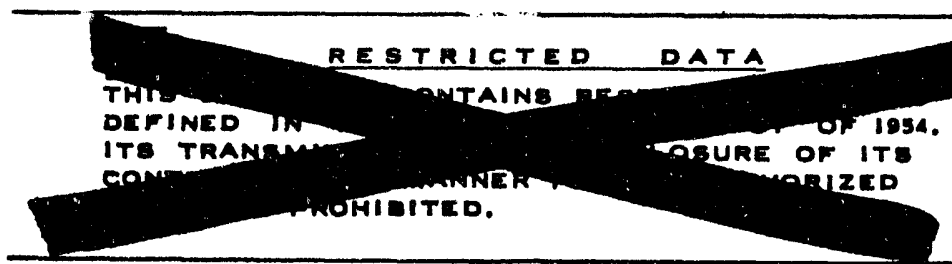

OTHER OFFICIAL CLAEEIFIED INFORMATION THIS MATERIAL CONTAINE INFORMATION AFFECTING THE NATIONAL DEFENBE OF THE UNITED BTATEB WITMIN THE MEANING OF THE EBPIONAGE LAWE. TITLE 16, U. B.C., SECS. TOS AND 704, THE TRANEMIEEION ON REVELATION OF WHICH IN ANY MANNE TO AN UNAUTHORIZED PERBON IS PROHIEITED DY LAW.
TITLE

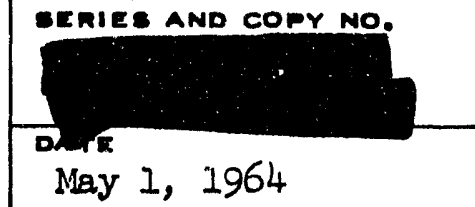

DRSIGN CRIIERIA

FISSION WASIE CONTAINER STORAGE FACIIITIES

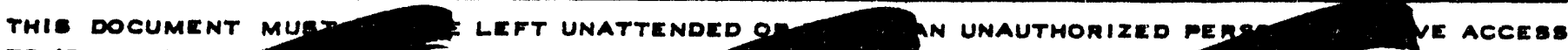
TO IT. WHEN NO TI MUST BE STORED

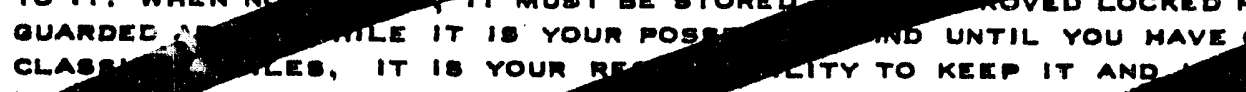

AUTMOR

J. W. Barnes TH TICT AND FROM ANY CTD PERSON. ITE TRAM ENTE WITHIN THE LIMIONED RECEIPT FRO

TAIN THEM FROM

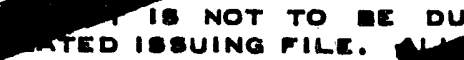
OVIDED EELOW.

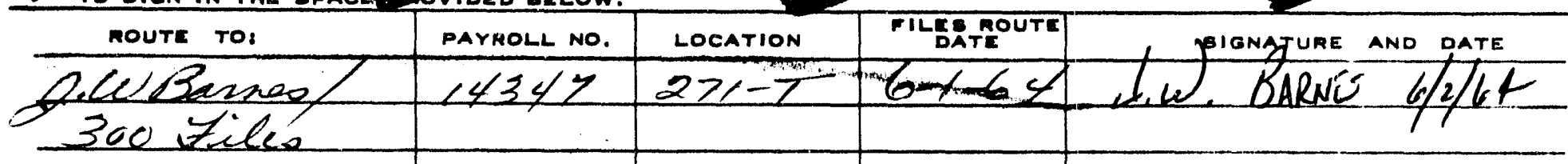




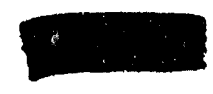

HW-81771. PT2 1 Page 1

This document classified by

This document consists
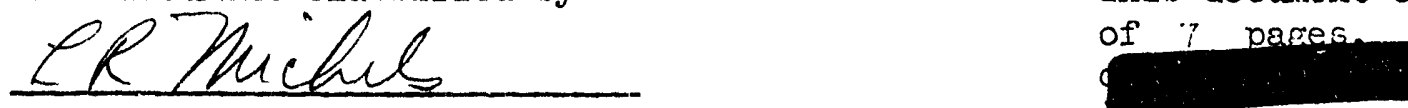

DESIGN CRITERIA

FISSION WASTTE CONTAINER STORAGE FACILITIES

By

J. W. Barnes

Process Design Engineering

Facilities Engineering

Chemical Processing Departnent
Clessification Cancelled and Changed to

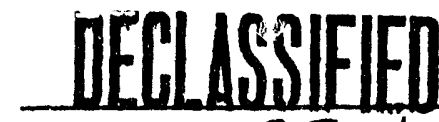

B) Authorty of 5EGydesen

$4-11-94, C 5-2 R-2$

By Ses Samely 4-1659

vortiod By fietri 2 haley,

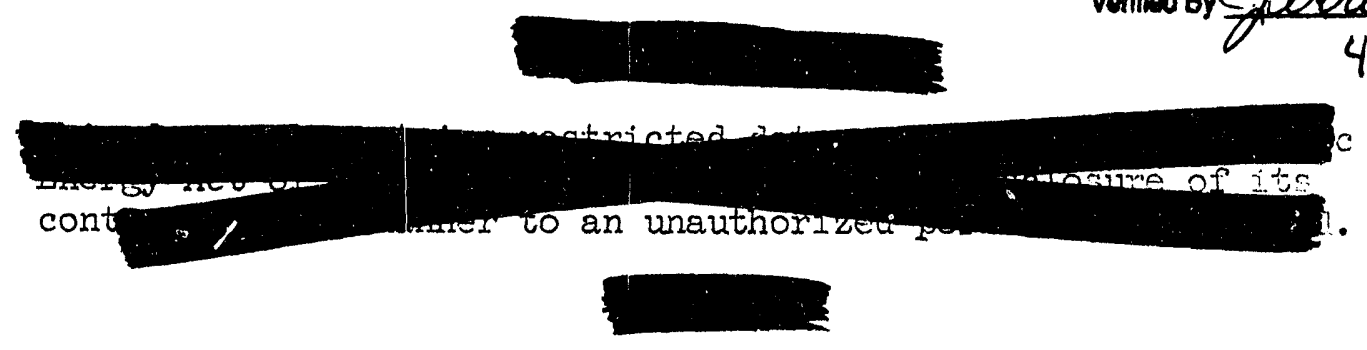

$4-18-94$.

This document has been reviewed and approved as a basis for project action.

Submitted by:
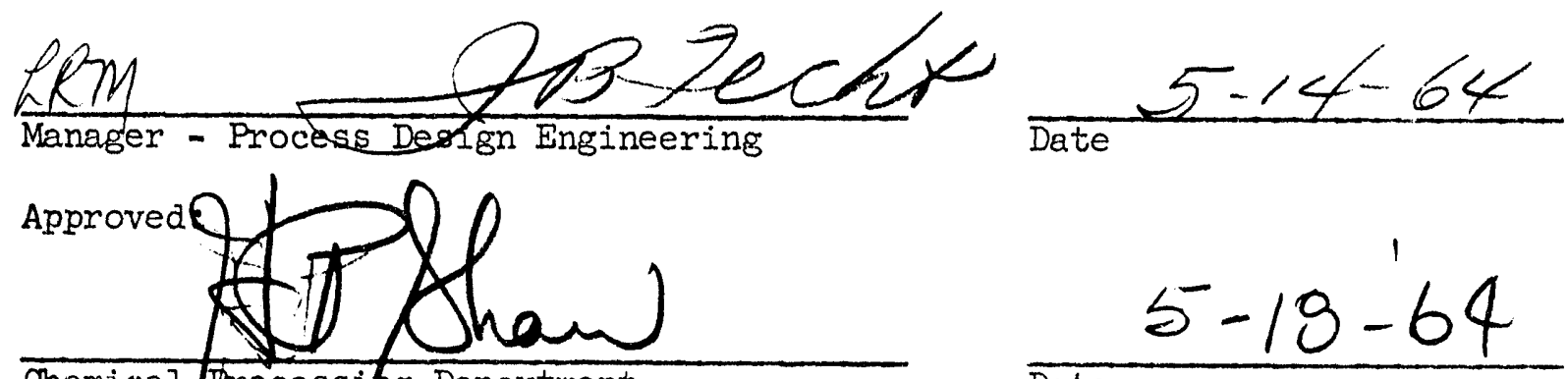

Chemical Processitg Department

General Electric Company

$$
5-10-64
$$

Date

Approved:

U. S. Atomic Energy Commission Richland Operations Office

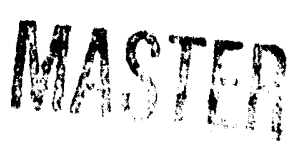

Date

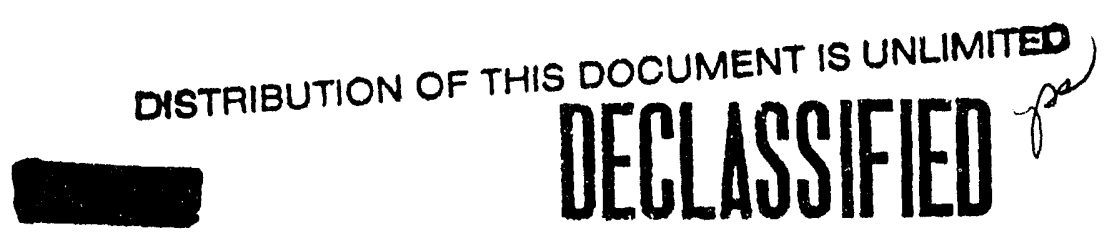




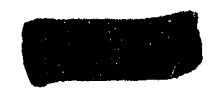

HW-81771 PT2 1 Page 2

\section{DISTRIBUTION}

\section{1-3. RLOO-AEC}

Attri: Mir. A. T. Gifford

4. HP Shaw

5. II Zahn

6. JW Barnes/300 Files

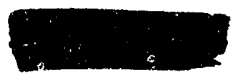


I. INITRODUCTION

4

II. DESIGN BASES

Container Production Rates

4

Heat Exchange System

5

III. DESIGN DATA SHEWTS

Exchanger Speclfications

Centrifugal Pump Spec1fication 
DESIGN CRITTERIA

FISSION WASTE CONTATIER STORAGE FACILITIES

\section{INITRODUCTION}

An unclassified design criteria for Fission Waste Container Storage Facilities is presented in HW-817TI PTI. The purpose of this document is to present classified information not given in HW-81771. PTI. This information deals with fission waste container production rates and fission waste inventories.

\section{DESIGN BASES}

\section{Container Production Rates}

Hot startup of the Phase II waste packaging demonstration unit is currently scheduled for January 1, 1966. A total of six containers will be produced during the demonstration phase. This number should provide for demonstration of a container loaded with strontium, one loaded with cesium, and one loaded with a mixture of the two isotopes. It also provides for one spare container each should a second derionstration unit be required. Each container will hold approximately 500 kilocuries of 1sotope and yield 8,000 to $12,000 \mathrm{BTU} / \mathrm{hr}$ of heat due to isotope decay.

Full scale container production is scheduled for the latter pant of 1965 following completion of the demonstration phase. An estimate 10 to 200 containers per year will be produced when full scale production retes are attained, with a possible 300 contalners per year being prociuced durine the first year if little debugging is required. A total of about one thousund 500-kdlocurie contalners will be produced over a five-to-seven-year pertio. and stored in.U-Plant.

Containers w1Il be transferred from B-Plant to U-Plant by railroad cask car at the above rate. These containers will be placed in the Pool CelI, Cell 4, and held for a surveillance perrlod of about 90 days. Visua: observation will be made through a minimum water cover of 14 feet. A total of 100 containers may be accomodated in Cell 4 by stacking two layers of cans on 30-inch centers.

The containers will be transferred to final storage in the storage basir located in Cells 1 and 2. A total of 120 containers may be stored per layer by placing the cans on 30-inch by 27-inch centers. A total of six layers or 720 containers may be stacked in this way by utilizing a support. grid or spacer between each layer of containers. Additional contalnens may be stored in Cell 4 to an ultimate capacity of 1,020 containers with 


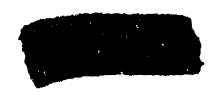

HW-817T1 PT2 1

Page 5

the present design. Increased capacity may be obtained in the future by sonverting Cells 6,7 , and 8 into additional storage cells. A total of 200 containers could be stored in each of these cells.

Heat Exchange System

Approximately $10 \mathrm{milli}$ ion BTU/hr will be released to the storage basins by the flssion waste isotopes when 1,020 containers are in storage. A closed loop cooling system has been installed in Cell 5 to remove this heat. This system is designed to circulate $500 \mathrm{gpm}$ of water and cool from $120 \% \mathrm{~F}$ to $80 \% \mathrm{~F}$. Two sets of exchangers and pumps are utijized to give two independent cooling systems so that removal of a pump or heat exchanger will still allow the storage basins to be maintained at a safe temperature. Further backup is provided by lines which allow the direct addition of demineralized or raw water from the cold side plpe gallery. Should all cooling systems fail, water temperatures within the basin would increase at no more than $12 \%$ per hour with 1,000 containers in storage.

The Primary Coolant Heat Exchangers, E-5-2 and E-5-3 are multipass shell and tube units with approximately $1,800 \mathrm{ft}^{2}$ of heat exchange surface. Significant cost savings may be realized in procurement by selecting a standard supplier's model and modifying the flanges to fit standard Hanford remote connectors. Specifications for these units are given in the attached data sheet.

Existing 150-gpn, 7-Inch, B.C. deep well purnps from U-Plant may be used Initially to elrculate primary coolant. Two new 250-gpm deep well pumps will be required to circulate primary coolant when the storage facility inventory exceeds 600 containers. Specifications for these pumps are siven in the attached data sheets. 
CHEMICAL P ROLESSING DEPARTMENT FACILITIES ENGINEERING OPERATION

EXCHANGER SPECIFICATIONS
HW-81771 PT2 1

Page 6

(Information Only)

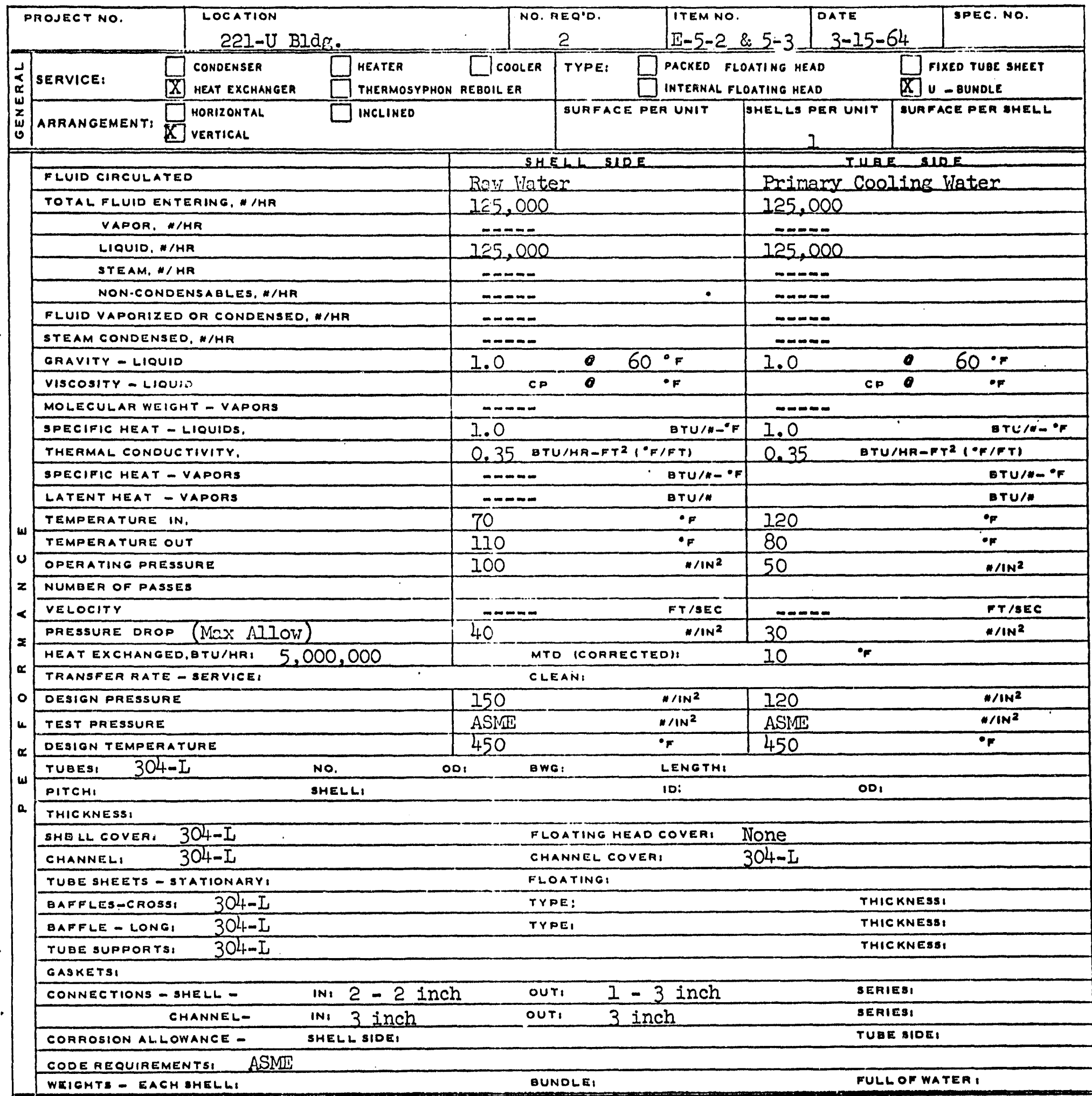

Exchanger dimensions \& flange orientations as shown on Drawings SK-2-19942 \& SK-2-19943. 


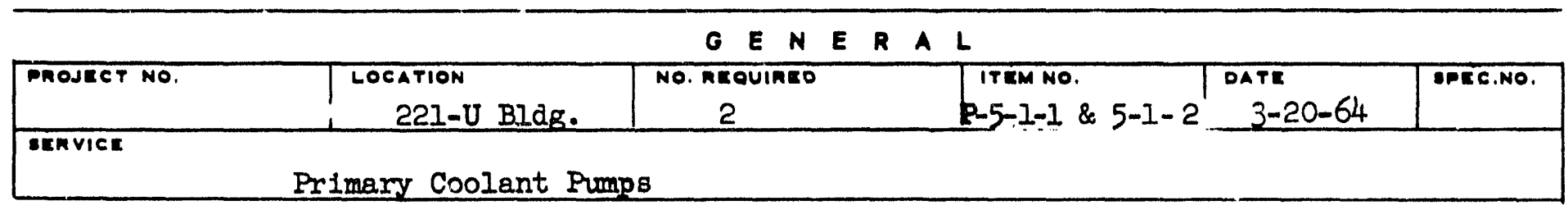

\begin{tabular}{|c|c|c|c|c|c|c|c|c|c|c|}
\hline LIQUID PUMPED & \multirow{2}{*}{\multicolumn{3}{|c|}{$\frac{\text { Prims.ry Cooling Water }}{\text { iric onaviry }}$}} & \multirow{2}{*}{ Triscosity } & \multirow[b]{2}{*}{1.0} & \multirow[b]{2}{*}{$\mathbf{C P}$} & \multicolumn{2}{|c|}{ PUMPINO TEMPERATURE (R.T.) } & \multirow[t]{2}{*}{95} & \multirow{2}{*}{$\frac{\text { OP }}{\text { PSIA }}$} \\
\hline - P.T. & & & & & & & VAPOR PRESBURE & 1.0 & & \\
\hline $0000 \mathrm{~F}$ & IPECIFIC ORAVitr & 1.0 & & VIscosity & 1.0 & CP & VAPOR PREBSUURE & 1.0 & & 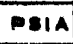 \\
\hline \multicolumn{2}{|c|}{ SOLIDS IN LIOUID, WT. S } & None & & DENEITY & $-\infty$ & & DARTICLE SIZE & $-\cdots$ & & \\
\hline \multicolumn{4}{|c|}{ CORnOBIVE COMPOUNDS } & & & & & & & \\
\hline
\end{tabular}

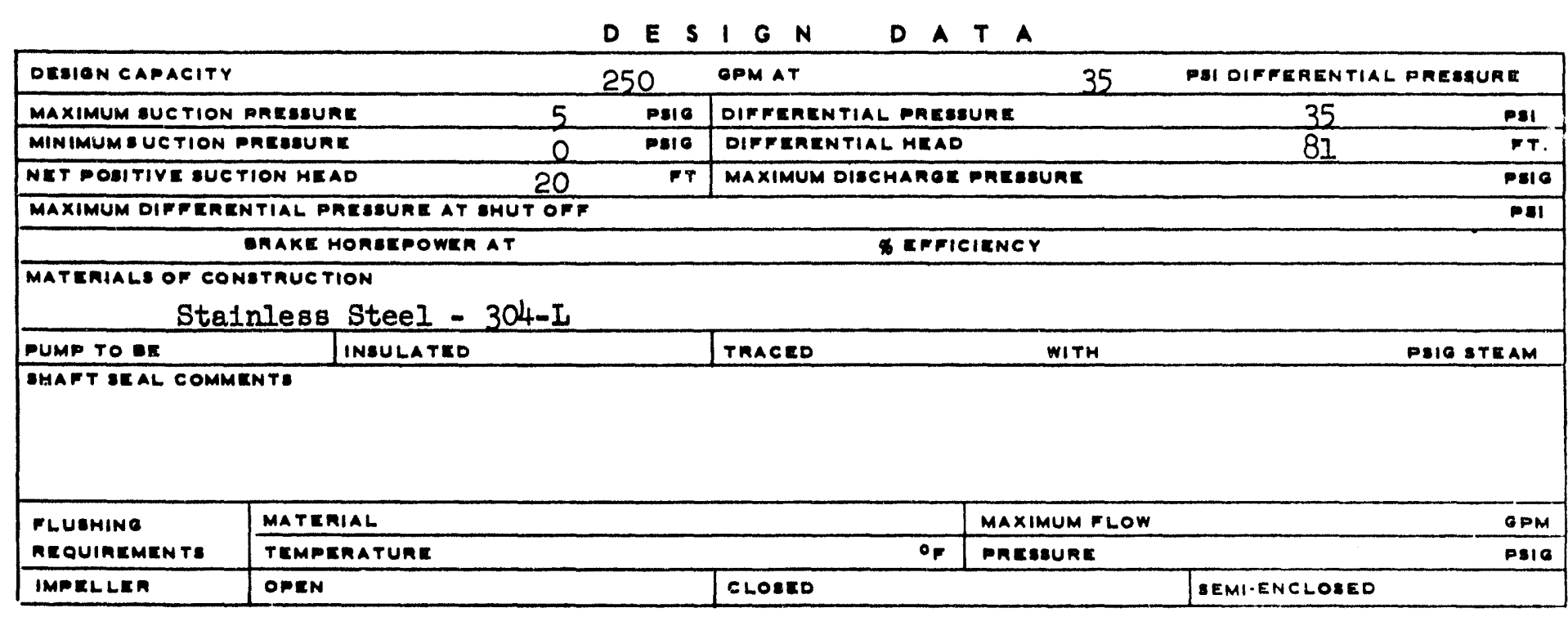

C O N N E C T IO N S

\begin{tabular}{|c|c|c|c|c|c|}
\hline SUCTION \&1ZE & SERIEA & TACINE & $\begin{array}{l}\text { DIschanar sizE } \\
\text { 3" Remote Nozzle }\end{array}$ & SERTES & FACING \\
\hline
\end{tabular}

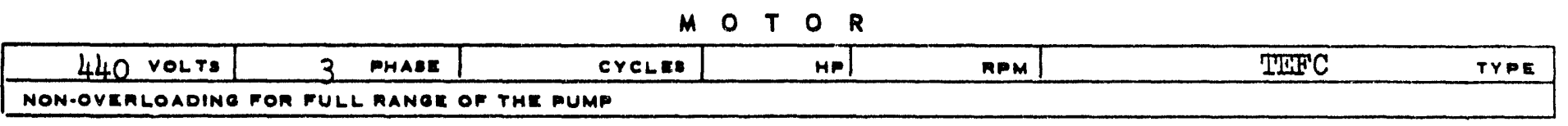

$$
\text { C A N Y O N P U M P S }
$$

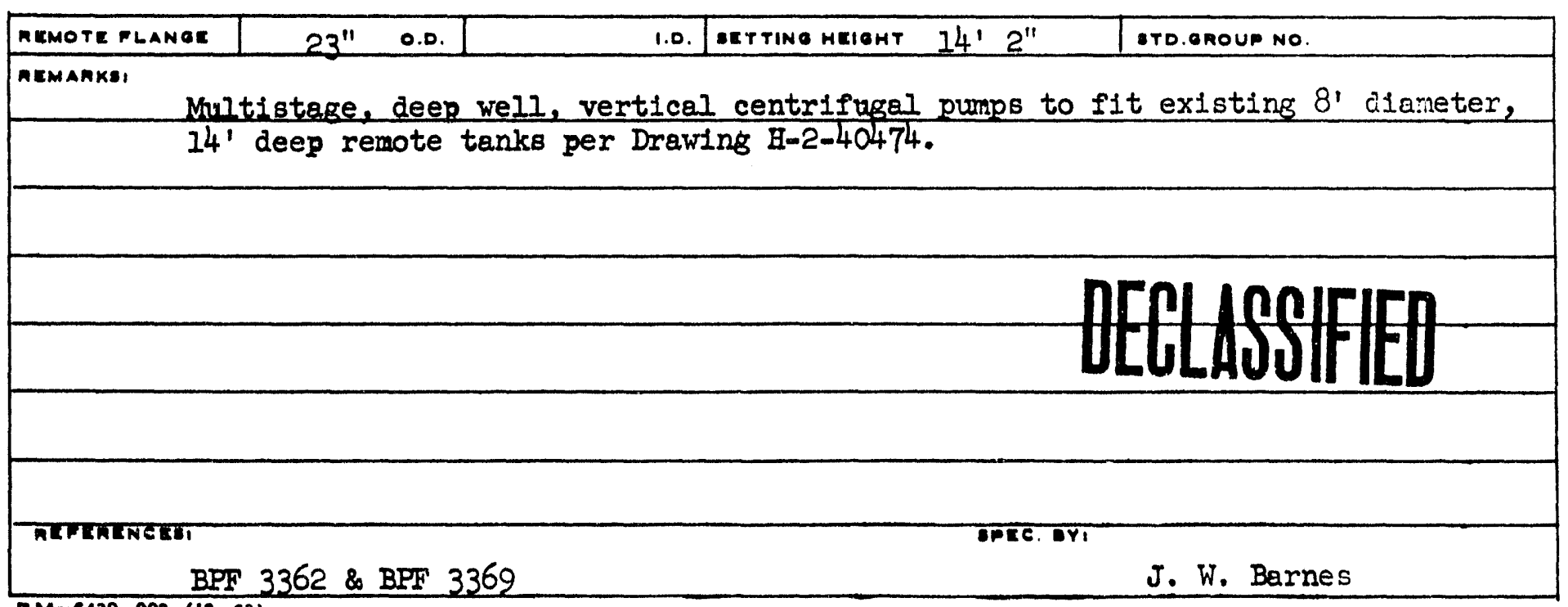



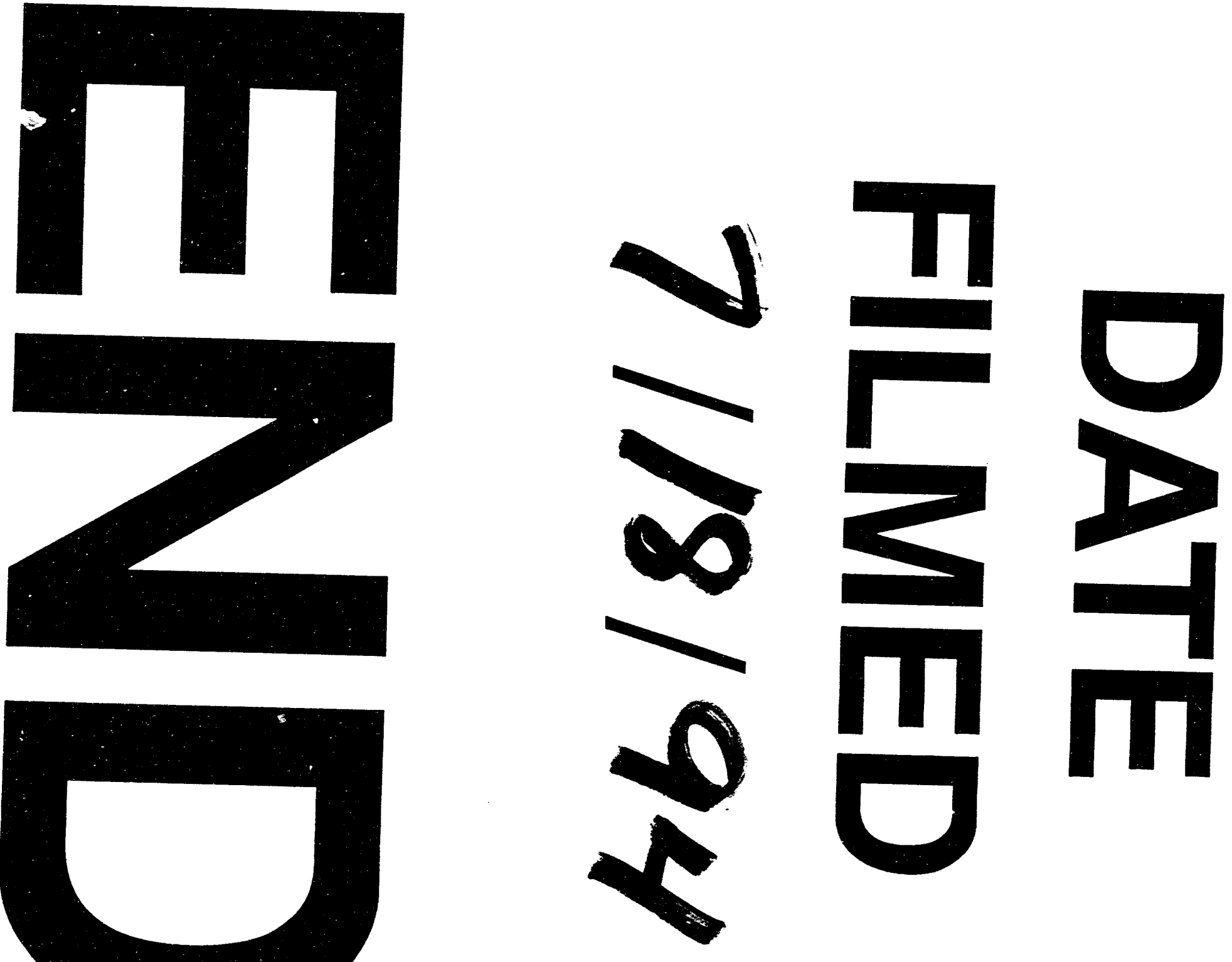

目

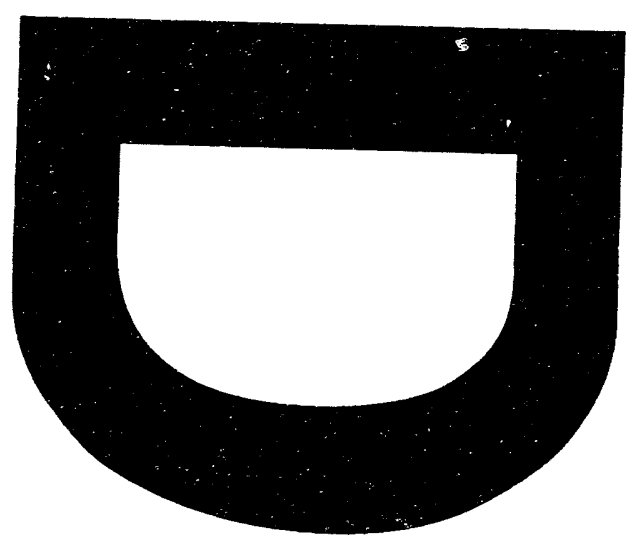




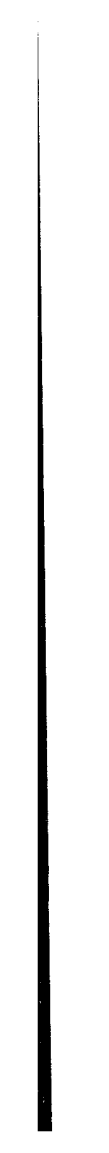

